\title{
Differentially expressed genes on the growth of mouse Leydig cells treated with standardised Eurycoma longifolia extract
}

\author{
NOR AMIRA KHURSHID AHMED ${ }^{1}$, SHERN KWOK LIM ${ }^{1}$, GANESH N. PANDIAN ${ }^{2}$, \\ HIROSHI SUGIYAMA ${ }^{2,3}$, CHONG YEW LEE ${ }^{4}$, BOON YIN KHOO ${ }^{1}$ and KIT LAM CHAN ${ }^{4}$ \\ ${ }^{1}$ Institute for Research in Molecular Medicine (INFORMM), Universiti Sains Malaysia, 11800 Penang, Malaysia; \\ ${ }^{2}$ World Premier International Research Initiative-Institute for Integrated Cell-Material Sciences (WPI-iCeMS), \\ Kyoto University, Kyoto 606-8501; ${ }^{3}$ Department of Chemistry, Graduate School of Science, Kyoto University, \\ Kyoto 606-8502, Japan; ${ }^{4}$ School of Pharmaceutical Sciences, Universiti Sains Malaysia, 11800 Penang, Malaysia
}

Received September 21, 2019; Accepted May 28, 2020

DOI: $10.3892 / \mathrm{mmr} .2020 .11485$

\begin{abstract}
Eurycoma (E.) longifolia Jack (Tongkat Ali) is a widely applied medicine that has been reported to boost serum testosterone and increase muscle mass. However, its actual biological targets and effects on an in vitro level remain poorly understood. Therefore, the present study aimed to investigate the effects of a standardised E. longifolia extract (F2) on the growth and its associated gene expression profile in mouse Leydig cells. F2, even at lower doses, was found to induce a high level of testosterone by ELISA. The level was as high as the levels induced by eurycomanone and formestane in Leydig cells. However, Leydig cells treated with F2 demonstrated reduced viability, which was likely due to the diminished cell population at the $\mathrm{G}_{0} / \mathrm{G}_{1}$ phase and increased cell population arrested at the S phase in the cell cycle, as assessed by MTT assay and flow cytometry, respectively. Cell viability was revived when the treatment time-point was prolonged to $96 \mathrm{~h}$. Genome-wide gene analysis by reverse transcription-quantitative PCR of F2-treated Leydig cells at $72 \mathrm{~h}$, when the cell growth was not revived, and $96 \mathrm{~h}$, when the cell growth had started to revive, revealed cyclin-dependent kinase-like 2 (CDKL2) to be a potential target in regulating the viability of F2-treated Leydig cells. Functional analysis, as analysed using
\end{abstract}

Correspondence to: Dr Boon Yin Khoo, Institute for Research in Molecular Medicine (INFORMM), Universiti Sains Malaysia, H53 Jalan Inovasi, 11800 Penang, Malaysia

E-mail: boonyin@usm.my

Abbreviations: EN, eurycomanone; FM, formestane; MTT, 3-(4,5-dimethylthiazol-2-yl)-2,5-diphenyltetrazolium bromide; OD, optical density; PI, propidium iodide; WT, whole transcript; ss, single-stranded; DEGs, differentially expressed genes; CDKL2, cyclin-dependent kinase-like 2; CBL, Casitas B-lineage lymphoma; Sphkap, SPHK1 interactor-AKAP domain-containing; DHEA, dehydroepiandrosterone

Key words: Eurycoma longifolia, testosterone, cell viability, cell cycle, gene expression profile, cyclin
GeneMANIA Cytoscape program v.3.6.0 (https://genemania. org/), further suggested that CDKL2 could act in concert with Casitas B-lineage lymphoma and sphingosine kinase 1 interactor-A-kinase anchoring protein domain-containing genes to regulate the viability of F2-treated Leydig cells. The findings of the present study provide new insights regarding the potential molecular targets associated with the biological effect of E. longifolia extract on cell growth, particularly on the cell cycle, which could aid in enhancing the bioefficacy and reducing the toxicity of this natural product in the future.

\section{Introduction}

Plant-based herbal medicines have been extensively applied traditionally for centuries. Recently, attention towards these types of medicine has increased worldwide owing to their nutraceutical value. Eurycoma (E.) longifolia Jack is one of the most popular traditional plants found in the tropical rainforests of Southeast Asia, especially in Malaysia and Indonesia. This herb belongs to the Simaroubaceae family that can grow slender up to $15 \mathrm{~m}$ high, able to grow in different types of soil (1-4). The plant is known locally as 'Tongkat Ali', 'Pasak Bumi', 'Cay ba binh' and 'Ian-don' in Malaysia, Indonesia, Vietnam and Thailand, respectively (5-7). $E$. longifolia is a promising natural source of biologically active compounds, including quassinoids, mainly those in the $13 \beta$ family, 18-dihydroeurycomanol, eurycomanol-2-O- $\beta$-D -glucopyranoside, eurycomanol and eurycomanone $(6,8,9)$. Some of the constituents of E. longifolia have been previously found to exert antiamoebic (10), in vitro anticancer or antiproliferative effects against cancer cells (11) and plasmodial activities (12). A previous study revealed that semi-purified eurycomanone conferred cytotoxic activity towards MCF-7 breast cancer cells, demonstrating the potential anticancer property of this plant $(9,13)$. In addition, E. longifolia root extract has also demonstrated significant cytotoxicity against human lung cancer (A-549) and human breast cancer (MCF-7) cell lines (14) in other previous studies.

A number of studies have previously demonstrated the efficacy of $E$. longifolia as an effective booster of testosterone and aphrodisiac supplement to improve strength and power during 
sexual activity $(15,16)$. Additionally, E. longifolia has been found to either prevent and/or alleviate erectile dysfunction in men (17). The roots and leaves of this plant have long been used to treat a number of diseases $(6,7)$. In addition to fever, intestinal parasites, mouth ulcers and headache $(6,18)$, the roots of E. longifolia have been applied as a traditional 'anti-aging' remedy to help older individuals adapt to the reduced energy, mood and libido associated with aging $(3,19)$. The roots of this plant have also been documented to enhance blood flow that function as an herbal supplement for women following childbirth $(6,20)$. By contrast, the leaves of the plant have been used to prevent gum diseases, treat ulcers and sexually-transmitted infections such as syphilis and gonorrhoea (3).

Leydig cells are the primary sites of steroidogenesis in the testis, which serve as the main source of testosterone in this organ (21). Testosterone production in Leydig cells is stimulated by luteinizing hormone, which is secreted by the anterior pituitary gland through the hypothalamic pituitary-gonadal axis (22). Testosterone is the primary male sex hormone, which is crucial for the differentiation of the male urogenital system, spermatogenesis and accumulation of bone and muscle mass in men (23).

The spermatogenic effect of E. longifolia is attributed to the presence of quassinoids in the extracts $(8,24)$. Quassinoids are biologically active compounds that contribute to $E$. longifolia as a testosterone production booster, such that extracts enriched with $E$. longifolia quassinoids have been found to exert more potent effects. The effects of E. longifolia extracts on steroidogenesis have been previously investigated in animal models (3,25-28). However, despite preliminary findings demonstrating the effect of quassinoid-rich E. longifolia on rat interstitial cells (8), the in vitro effects of E. longifolia extracts in Leydig cells, for example, remain poorly understood. Therefore, the present study aimed to investigate the impact of a standardized E. longifolia root extract (F2) on testosterone production, growth and cell cycle progression in mouse Leydig cells. It is hoped that data from the present study will lead to an improved understanding on the mechanism of action mediated by the E. longifolia extract so it can be further utilized as a natural product for treating human diseases.

\section{Materials and methods}

E. longifolia standardised extract and chemical preparation. A standardised root methanolic extract of E. longifolia, F2, and the pure compound, eurycomanone (EN; $>96 \%$ purity), were received from Professor Chan Kit Lam at the School of Pharmaceutical Science, Universiti Sains Malaysia (Penang, Malaysia). Both the extract and the pure compound were dissolved in double-sterile water $\left(\mathrm{ddH}_{2} \mathrm{O}\right)$. The aromatase inhibitor, formestane (FM; >98\% purity), which was purchased from MedChem Express, was dissolved in DMSO.

TM3 cell culture. TM3 (CRL-1714 ${ }^{\mathrm{TM}}$ ) Leydig cells, purchased from the American Type Culture Collection, were cultured in a 1:1 mixture of Gibco Ham's F12 medium (Invitrogen; Thermo Fisher Scientific, Inc.) and Dulbecco's modified eagle's medium (DMEM; Invitrogen; Thermo Fisher Scientific, Inc.) supplemented with $5 \%(\mathrm{v} / \mathrm{v})$ horse serum (Invitrogen; Thermo Fisher Scientific, Inc.) and $2.5 \%(\mathrm{v} / \mathrm{v})$ foetal bovine serum (Invitrogen; Thermo Fisher Scientific, Inc.). Penicillin $(100 \mathrm{U} / \mathrm{ml})$ and streptomycin $(100 \mu \mathrm{g} / \mathrm{ml})$ were added to the growth medium to prevent contamination. The culture was incubated in a humidified atmosphere and supplied with $5 \% \mathrm{CO}_{2}$ at $37^{\circ} \mathrm{C}$. The Leydig cells were sub-cultured every 2-3 days depending on the confluence of the cell culture. The use of a mouse Leydig cell line may be a limitation of the present study. Human Leydig cells would have been a better cell line for proper verification of the hypothesis.

Measurement of testosterone levels in F2-, EN- and FM-treated Leydig cells using ELISA. TM3 cells were seeded onto 24 -well plates at a density of $2.0 \times 10^{4}$ cells/well. After being cultured at $37^{\circ} \mathrm{C}$ in an incubator overnight, the cells were treated with $0.1,1.0$ and $10 \mathrm{mg} / \mathrm{ml} \mathrm{F} 2$ or $0.1,1.0$ and $10 \mu \mathrm{M} \mathrm{EN}$ or FM. Each treatment was carried out in triplicate for four treatment time-points: 24, 48, 72 and $96 \mathrm{~h}$ in $\geq 2$ independent experiments, following which the culture supernatant was collected at each treatment time-point. The collected culture supernatants were used for the measurement of testosterone level using a mouse testosterone (T) enzyme-linked immunosorbent assay (ELISA) kit (cat. no. CSB-E05101m; Cusabio Biotech Co., Ltd.), according to the manufacturer's instructions. Briefly, the wells of the microtitre plates were pre-coated with a goat anti-rabbit antibody specific for testosterone. The reactions were then incubated with a secondary horseradish peroxidase-conjugated antibody from the aforementioned kit for the target hormone signal development. A substrate solution was also added to enhance the color development to indicate the presence of the target hormone. The intensity of the signal for each plate was measured at $450 \mathrm{~nm}$ by using a Multiskan ${ }^{\mathrm{TM}}$ spectrum spectrophotometric plate reader (Thermo Fisher Scientific, Inc.). A standard curve was plotted to estimate the level of testosterone (\% relative to control) in each well.

Viability analysis of F2-, EN- and FM-treated Leydig

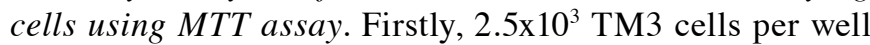
were seeded onto 96 -well plates. The cells were cultured overnight in growth medium at $37^{\circ} \mathrm{C}$ and treated with 0.1 , 1.0 , and $10 \mathrm{mg} / \mathrm{ml} \mathrm{F} 2$ and $0.1,1.0$ and $10 \mu \mathrm{M}$ EN or FM in triplicate for four treatment time-points: $24,48,72$ and $96 \mathrm{~h}$ for $\geq 2$ independent experiments at $37^{\circ} \mathrm{C}$. Cell viability was measured by using a standard 3-(4,5-dimethylthiazol-2-yl)-2,5-diphenyltetrazolium bromide (MTT) assay. At each time-point, $24 \mu \mathrm{l}$ MTT reagent $(2.5 \mathrm{mg} / \mathrm{ml})$ was added to each well before the reactions were incubated for $4 \mathrm{~h}$ at room temperature. Subsequently, $100 \mu \mathrm{l}$ DMSO was added to each well for color development. The color or optical density (OD) was then read at $570 \mathrm{~nm}$ by using a Multiskan ${ }^{\mathrm{TM}}$ spectrum spectrophotometric plate reader (Thermo Fisher Scientific, Inc.). The cell viability in each well was calculated using the following formula: [(OD of treated sample-OD of blank)/(OD of control-OD of blank)] x $100 \%$. The level of cell viability was indicated as $\%$ relative to control.

Cell cycle progression analysis of F2-treated Leydig cells using flow cytometry. A density of $6.0 \times 10^{4} \mathrm{TM} 3$ cells/well was seeded onto 6-well plates and incubated at $37^{\circ} \mathrm{C}$ with $5 \% \mathrm{CO}_{2}$ overnight. On the next day, the cells were treated with $\mathrm{F} 2$ at concentrations of $0.1,1.0$ and $10 \mathrm{mg} / \mathrm{ml}$ in triplicate at $37^{\circ} \mathrm{C}$ for 
four treatment time-points: $24,48,72$ and $96 \mathrm{~h}$ in $\geq 2$ independent experiments. The culture supernatants and the cells were then harvested from each well and transferred to new $15 \mathrm{ml}$ Falcon tubes at each time-point. The tubes were centrifuged at $1,000 \times \mathrm{g}$ for $5 \mathrm{~min}$. The supernatant was discarded, and the cell pellet was washed with PBS and centrifuged again at $1,000 \mathrm{x} \mathrm{g}$ for $5 \mathrm{~min}$. After discarding the supernatant, $500 \mu \mathrm{l}$ PBS was added to the cell pellets. All these procedures were carried out at room temperature. The number of cells in the cell suspension was then counted and adjusted to $1 \times 10^{6}$ cells, which was suspended in $500 \mu \mathrm{l}$ using $70 \%$ cold absolute ethanol. The suspension was mixed gently and stored at $4{ }^{\circ} \mathrm{C}$ to facilitate ethanol fixation. Before cell cycle analysis, the ethanol-fixed cells were centrifuged at $1,000 \mathrm{x} \mathrm{g}$ for $10 \mathrm{~min}$ and washed three times by resuspending the cells in PBS at room temperature. The suspension was then centrifuged again at $1,000 \times \mathrm{g}$ at room temperature for $10 \mathrm{~min}$ and the supernatant was discarded. The cells were stained with $500 \mu \mathrm{l}$ FxCycle $^{\mathrm{TM}}$ propidium iodide (PI)/RNase staining solution (Thermo Fisher Scientific, Inc.) at room temperature in the dark for $30 \mathrm{~min}$. The stained samples were then transferred to new sterile flow tubes and maintained on ice until the samples were analysed by flow cytometry using a BD FACSCanto ${ }^{\mathrm{TM}}$ II flow cytometer (BD Biosciences). The \% of the cell population at each cell cycle phase was then calculated.

mRNA gene expression profile analysis of F2-treated Leydig cells. TM3 cells were seeded onto 24-well plates at a density of $2.0 \times 10^{4}$ cells/well and incubated at $37^{\circ} \mathrm{C}$ with $5 \% \mathrm{CO}_{2}$ overnight. The next day, cells were treated with $500 \mu 10.1 \mathrm{mg} / \mathrm{ml}$ F2 in triplicate for 72 and $96 \mathrm{~h}$. A total of three wells of treatment solution and treated cells were then harvested and pooled as one sample for RNA extraction. The total RNA extraction was performed by using the RNeasy Mini Kit (QIAGEN Inc.), according to the manufacturer's protocol. The concentration and purity of the extracted total RNA were determined by using a NanoPhotometer ${ }^{\circledR}$ (Implen GmbH), whereas the integrity of the RNA was assessed by $1 \%$ (w/v) agarose gel electrophoresis (Bio-Rad Laboratories Inc.). The integrity of the total RNA was confirmed further using a 2100 Bioanalyzer (Agilent Technologies Inc.) coupled with the RNA 6000 Pico LabChip ${ }^{\circledR}$ Kit (cat. no. 5067-1513; Agilent Technologies Inc.). Good quality RNA (showing 2 ribosomal peaks and RNA Integrity Number $\geq 8$ ) was used for steroidogenesis gene expression profiling using Affymetrix GeneChip ${ }^{\mathrm{TM}}$ microarray technology (Thermo Fisher Scientific, Inc.). The copy RNA (cRNA) targets for the Affymetrix platform were synthesized, purified, labelled and hybridised, according to the manufacturer's instructions. Briefly, $100 \mathrm{ng}$ extracted total RNA was converted to cDNA and was then amplified to cRNA following the procedures of Affymetrix GeneChip ${ }^{\mathrm{TM}}$ Whole Transcript (WT) PLUS Reagent Kit (cat. no. 902280; Thermo Fisher Scientific, Inc.). The cRNA was then purified and quantified before being synthesised into single-stranded (ss)-cDNA using the same kit, according to the manufacturer's protocols. The ss-cDNA was then fragmented and labelled with biotin before being hybridised onto the array strip for GeneChip ${ }^{\mathrm{TM}}$ WT Expression Array (Affymetrix; Thermo Fisher Scientific, Inc.). The gene expression profiles were scanned using the Affymetrix GeneArray scanner 3000 7G system (Affymetrix;
Thermo Fisher Scientific, Inc.) at $488 \mathrm{~nm}$ and 3- $\mu \mathrm{m}$ resolution. The images of the patterns were analysed using the Affymetrix Microarray Suite software v.5.0 (MAS5). The raw data .txt file obtained from the GeneArray scanner was then loaded onto the GeneSpring Gx software v.12.0 (Agilent Technologies Inc.) for further data processing, including normalization and statistical analysis. The expression ratios for $>22,000$ genes in non-treated and F2-treated Leydig cells at the respective time-points were computed and filtered by comparative analysis of the MAS5 values. The $\log _{2}$ values were used to identify differentially expressed genes (DEGs) in F2-treated compared with non-treated Leydig cells. Genes with a fold-change $\geq 2$ were identified as statistically significant DEGs.

Identified gene expression validation in F2-treated Leydig cells using reverse transcription-quantitative $(R T-q) P C R$. Leydig cells were seeded onto 24 -well plates at a density of $2.0 \times 10^{4}$ cells/well and incubated at $37^{\circ} \mathrm{C}$ with $5 \% \mathrm{CO}_{2}$ overnight. The next day, the cells were treated with $500 \mu$ l either 0.1 or $1.0 \mathrm{mg} / \mathrm{ml} \mathrm{F} 2$ in triplicate for 72 and $96 \mathrm{~h}$. A total of three wells of treatment solution and treated cells were then harvested and pooled as one sample for RNA extraction using the RNeasy Mini Kit (QIAGEN Inc.), according to manufacturer's protocols. The concentration of the extracted total RNA was determined by using a NanoPhotometer and the integrity of extracted RNA was assessed by using $1 \%$ (w/v) agarose gel electrophoresis as aforementioned. Good quality total RNA was reverse-transcribed to cDNA at $60^{\circ} \mathrm{C}$ using the RevertAid First Strand cDNA Synthesis Kit (Thermo Fisher Scientific, Inc.) and the cDNA was stored at $-20^{\circ} \mathrm{C}$ until it was used to analyse the gene expression by qPCR. All primers used were designed using the Primer Express ${ }^{\mathrm{TM}}$ software v.3.0.1 (Thermo Fisher Scientific, Inc.) and are listed in Table I. qPCR was performed by using the Applied Biosystems Power SYBR $^{\circledR}$ Green PCR Master Mix and the 7500 Fast Sequence Detection System (both Thermo Fisher Scientific, Inc.). Each reaction mixture contained $12.5 \mu \mathrm{l}$ of $2 \mathrm{X} \mathrm{SYBR}{ }^{\circledR}$ Green PCR Master Mix, 20 pmol each of forward and reverse primer and $5 \mu \mathrm{l}$ cDNA (25 ng). A sufficient volume of deionised water was added to the mixture to bring the final reaction volume to $25 \mu \mathrm{l}$. The following thermocycler program was used for the amplification: $50^{\circ} \mathrm{C}$ for $3 \mathrm{~min}$ and $95^{\circ} \mathrm{C}$ for $5 \mathrm{~min}$ for initiation, followed by $35-40$ cycles of $95^{\circ} \mathrm{C}$ for $10 \mathrm{sec}$ and $60^{\circ} \mathrm{C}$ for $30 \mathrm{sec}$. Finally, a melting curve for each amplicon was generated with $1^{\circ} \mathrm{C}$ temperature increments from $72-95^{\circ} \mathrm{C}$. All reactions were performed in triplicate and included three non-template reactions as negative controls. The experiment was repeated $\geq 2$ times, whereby the mRNA expression levels of the target genes were normalised to that of $\beta$-actin in the test sample. The mRNA expression level (relative to control) of the target gene was then calculated using the $2^{-\Delta \Delta C q}$ method (29).

Functional enrichment analysis. To further study the interaction of identified DEGs at a functional level, Gene Ontology (GO) functional enrichment analysis was performed using GeneMANIA Cytoscape program v.3.6.0 (https://genemania. org/). GeneMANIA discovered functionally similar genes using a wealth of genomics and proteomics data from a query gene. The algorithm of the modal was then weighted each 
Table I. List of primers used for quantitative PCR analysis.

Gene name

Primer sequence

\section{$C D K L 3$}

Cyclin G1

CDKN1A

Cyclin L1

$C D K L 2$

HMOX1

Cyclin $G 2$

Cyclin B2

CDKN2C

$\beta$-actin
Forward: 5'-TGTCCTCCTGTCTGGTGCATT-3'

Reverse: 5'-CTACCCGAGAAGACCCTTTTCAG-3' Forward: 5'-AAGGTACAGGCGAAGCATCTTG-3'

Reverse: 5'-CCTTTCCTCTTCAGTCGCTTTC-3'

Forward: 5'-GACCACTGGACCTAGCAATTCAC-3'

Reverse:5'-GTAGGAGTCACCGTCCTGTTTACC-3'

Forward: 5'-AATAGGCGAAGTCGATCTGGAA-3'

Reverse: 5'-TATGATGTCTTCGAGGGCTTTCA-3'

Forward: 5'-CAAATGCCAACTGTCTCCATGA-3'

Reverse: 5'-GTTGACATTGCTGCAATCTCTGA-3'

Forward:5'-GGTGTCCAGAGAAGGCTTTAAGC-3'

Reverse: 5'-TGCGCTCTATCTCCTCTTCCA-3'

Forward: 5'-GGAGTGTTTTGATCCCCAACA-3'

Reverse: 5'-GAACAGCTAAGGATGACCTCGAA-3'

Forward: 5'-GTGAAGTCCTGGAAGTCATGCA-3'

Reverse: 5'-CGATGAACTTGGTACGGTTGTC-3'

Forward: 5'-AACCATCCCAGTCCTTCTGTCA-3'

Reverse: 5'-CCCCTTTCCTTTGCTCCTAATC-3'

Forward: 5'-GCTCTGGCTCCTAGCACCAT-3'

Reverse: 5'-GCTGATCCACATCTGCTGGAA-3'

CDKL3, cyclin-dependent kinase-like-3; CDKN1A, cyclin-dependent kinase inhibitor 1A; CDKL2, cyclin-dependent kinase-like 2; HMOX1, heme oxygenase 1 ; CDKN2C, cyclin-dependent kinase inhibitor $2 \mathrm{C}$.

functional genomic dataset, according to its predictive value for the query, whereby a fold change discovery $\leq 0.05$ was set as the cut-off criterion for the enrichment analysis (30). A diagram of network weight for CDKL2 was plotted by $-\log 10$ (DWeight).

Statistical analysis. All data were presented as the means \pm standard deviation from experimental triplicates, and all statistical analyses were performed using GraphPad Prism 7.05 (GraphPad Software, Inc.). The significant levels of cell viability, hormone and target gene expression were analysed by using one-way ANOVA with the Tukey's post hoc test. $\mathrm{P}<0.005$ was considered to indicate a statistically significant difference.

\section{Results}

Comparison of testosterone production in F2-, EN- and FM-treated Leydig cells. Testosterone levels in culture supernatants of F2- and EN-treated TM3 cells, as measured by ELISA, were first inhibited $24 \mathrm{~h}$ after treatment. Following that, the levels were induced with increasing treatment time-points compared with those of control (Fig. 1A and B), indicating the ability of F2 to stimulate testosterone production by these cells. The experiments further validated the highest activity of F2 on hormone production by TM3 cells $96 \mathrm{~h}$ after treatment. FM, a known aromatase inhibitor, also demonstrated a similar effect and induced high levels of testosterone production in TM3 cells but only $\geq 72 \mathrm{~h}$ after treatment with the highest concentration of FM (10 $\mu \mathrm{M})$ tested (Fig. 1C). Therefore, these results suggest that F2 and EN may exert similar effects as aromatase inhibitors in regulating testosterone synthesis and production. In addition, it should also be noted that high levels of testosterone production ( $250 \%$ increase) were also observed in F2-treated TM3 cells even at lower concentrations ( 0.1 and $1.0 \mathrm{mg} / \mathrm{ml}$; Fig. 1A). Therefore, F2 may be more potent at stimulating testosterone production compared with $\mathrm{EN}$ and FM in Leydig cells.

Reduced cell viability of F2-, EN-and FM-treated Leydig cells compared with control cells. According to the results from MTT assay (Figs. 2-4), a significant reduction in the viability of F2-, EN- and FM-treated TM3 cells was observed compared with that of their corresponding controls in a dose-dependent manner. Treatment of Leydig cells with F2 demonstrated a significant reduction in cell viability at all concentrations and treatment time-points tested (Fig. 2). The viability of TM3 cells treated with lower concentrations of F2, including $0.1,0.5$ and $1.0 \mathrm{mg} / \mathrm{ml}$, were able to revive $96 \mathrm{~h}$ following treatment, although the viability of the treated cells remained low at this treatment time-point (Fig. 2D). Notably, a less potent inhibitory effect on cell viability was observed for EN, whereby cell treated with EN were viable throughout all experimental time-points tested (Fig. 3). A gradual increment of cell viability inhibition on TM3 was only observed when higher concentrations of EN, including 1, 5 and $10 \mu \mathrm{M}$ were used (Fig. 3). In the FM-treated cells, a stronger growth inhibitory effect was observed at earlier 


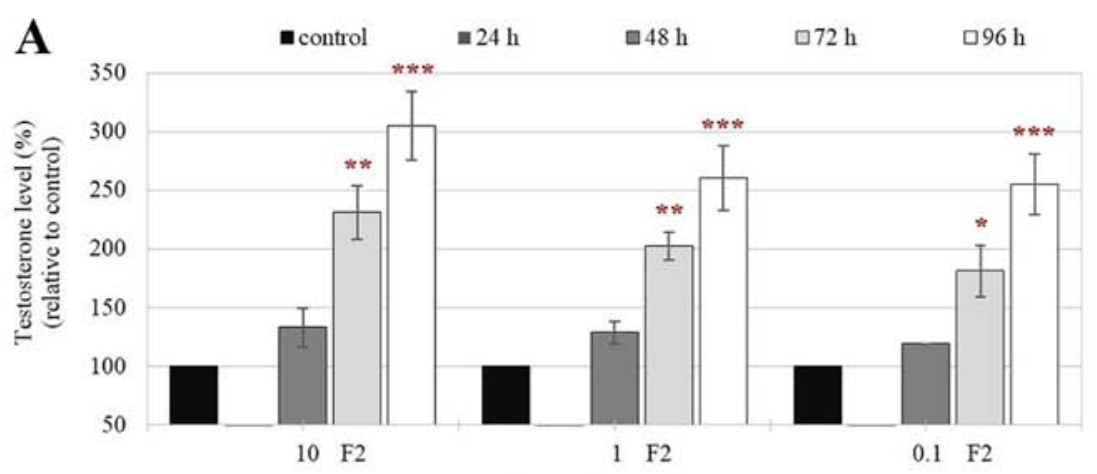

Treatment concentration $(\mathrm{mg} / \mathrm{ml})$
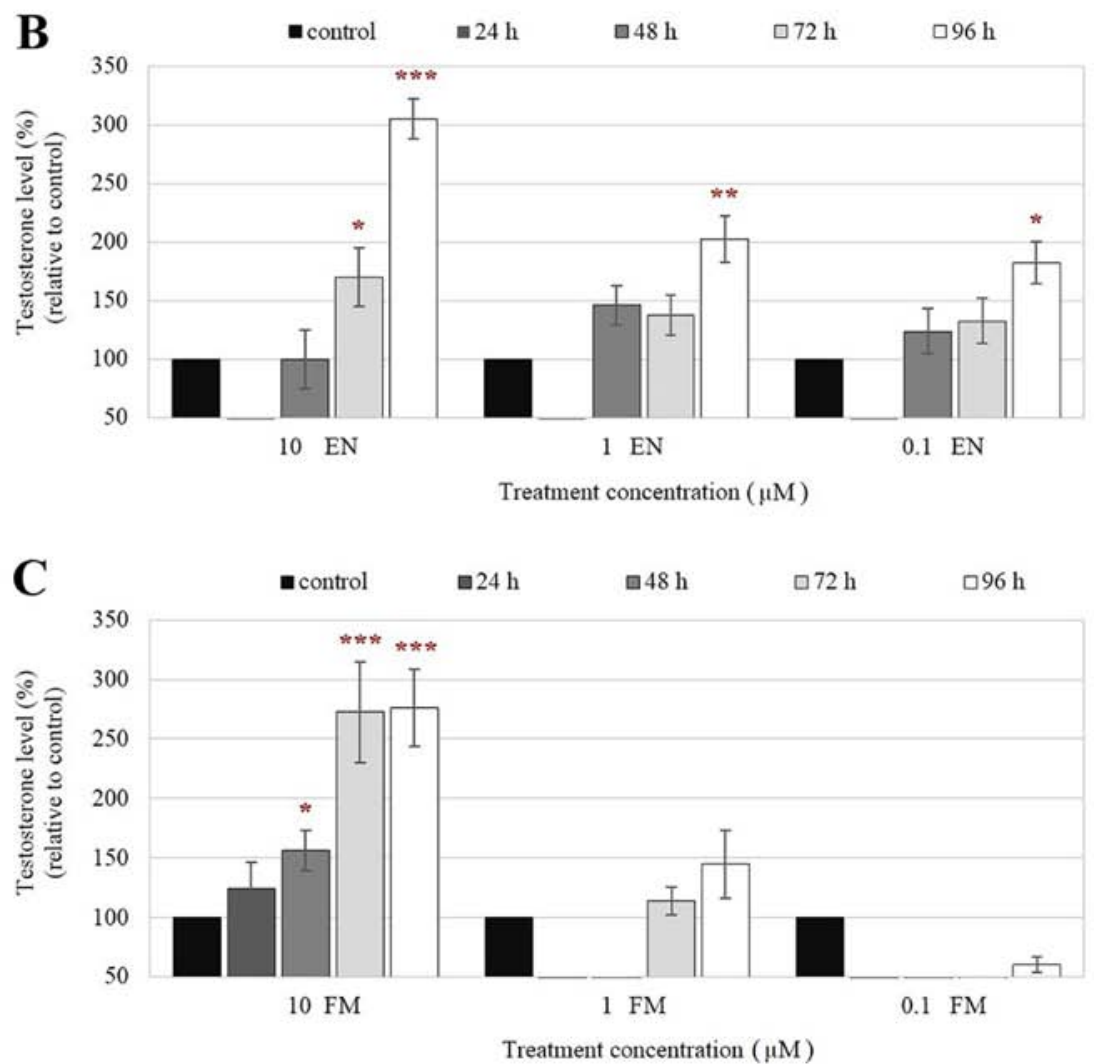

Figure 1. Level of testosterone in the culture supernatants of Leydig cells treated with different concentrations of F2, FM and EN. Testosterone production by TM3 cells was measured following treatment with (A) F2, (B) EN and (C) FM. Data are expressed as means \pm SD (n=3). ${ }^{*} \mathrm{P}<0.05,{ }^{* *} \mathrm{P}<0.01$ and ${ }^{* * *} \mathrm{P}<0.001$ indicate a significant induction of testosterone level at specific time-points vs. the level at 0 h (control). EN, eurycomanone; FM, formestane; F2, Eurycoma longifolia extract.

treatment time-points compared with that observed in EN treated cells (Fig. 4). Notably, the FM-treated cells remained viable at $96 \mathrm{~h}$, although a dose-dependent inhibition of cell viability was also observed at higher concentrations (5 and $10 \mu \mathrm{M}$ ) of FM treatment (Fig. 4D). The revival of the treated cells could be attributed to the reduction in the drug effect with prolonged treatment duration. Therefore, F2, EN and FM are suitable for long term treatments of Leydig cells at low concentrations.

S-phase cell cycle arrest in F2-treated Leydig cells. Cell cycle analysis of TM3 cells by flow cytometry (Fig. 5A) demonstrated that the percentage of cells at the $G_{0} / G_{1}$ phase was significantly reduced after treatment with $0.1,1.0$ and $10 \mathrm{mg} / \mathrm{ml}$ compared with that in the untreated cells (control)
$24 \mathrm{~h}$ after treatment (Fig. 5B). The reduced percentage of F2-treated TM3 cells at the $G_{0} / G_{1}$ phase was accompanied by an accumulation in the percentage of cells at the $S$ phase (Fig. 5B). This phenomenon suggests that the growth of F2-treated cells was affected by cell cycle arrest in the $S$ phase. This observation persisted $48 \mathrm{~h}$ following treatment, particularly in the cells treated with higher concentrations of F2 (1.0 and $10 \mathrm{mg} / \mathrm{ml}$; Fig. 5C). However, the percentage of cells in the $G_{0} / G_{1}$ phase appeared to be revived $48 \mathrm{~h}$ after treatment with $0.1 \mathrm{mg} / \mathrm{ml} \mathrm{F} 2$ (Fig. 5C). The opposite trend was observed in the percentage of cells in the $\mathrm{S}$ phase (Fig. 5C). Cells treated with higher concentrations of F2 were only revived $72 \mathrm{~h}$ following treatment (Fig. 5D); the number of cells in Go/G1 cell cycle phase $72 \mathrm{~h}$ following treatment was higher compared with the number of cells in the same phase 
$\mathbf{A}_{\mathrm{F} 2,24 \mathrm{~h}}$
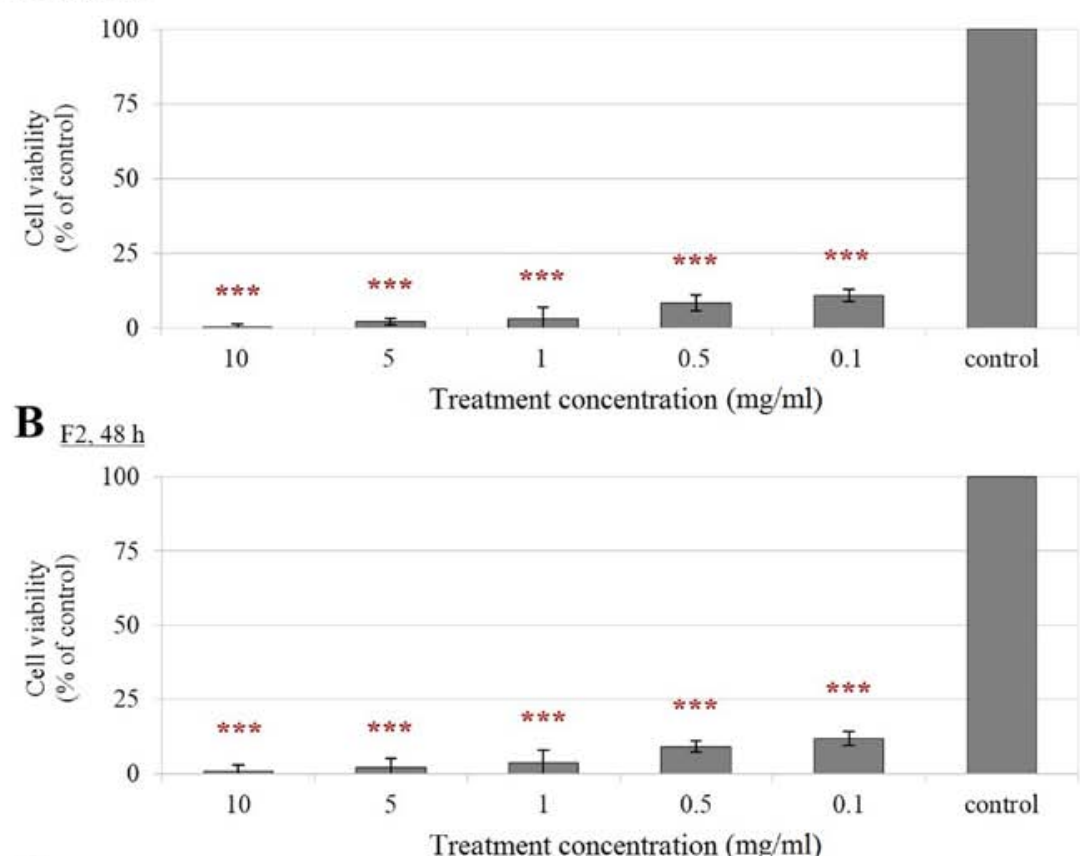

C

F2.72h

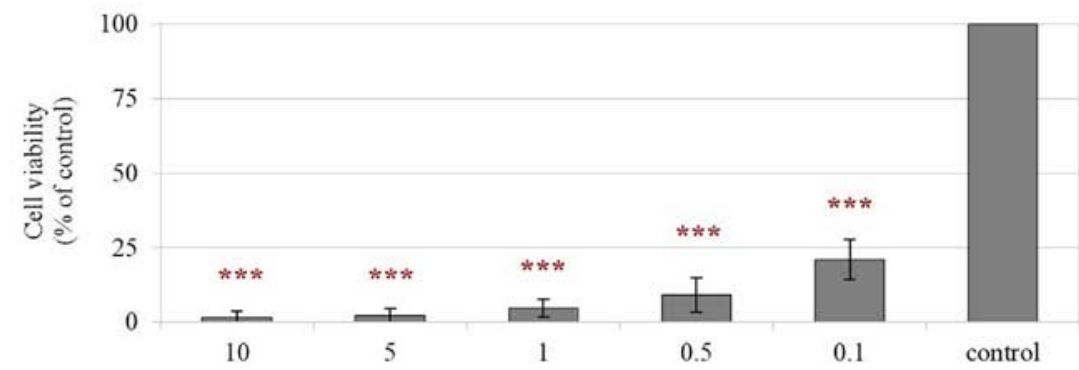

D

Treatment concentration $(\mathrm{mg} / \mathrm{ml})$

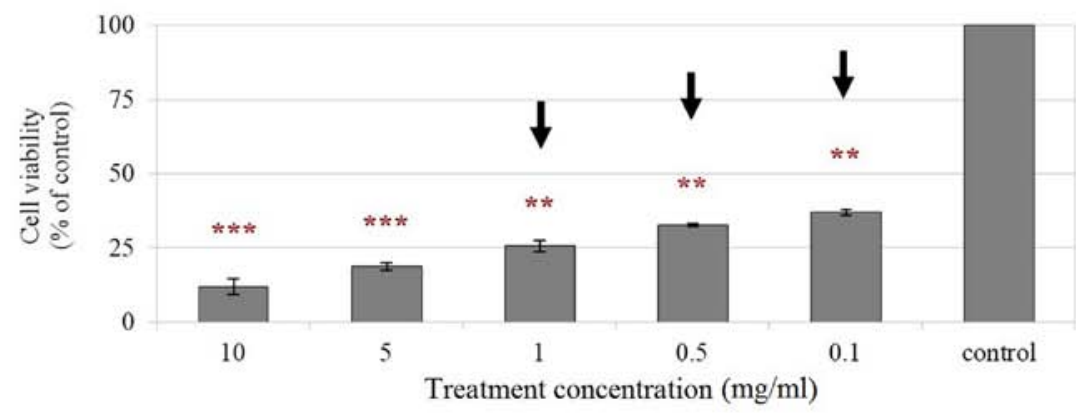

Figure 2. Effects of F2 treatment on Leydig cell viability. Viability of TM3 cells was measured (A) 24, (B) 48, (C) 72 and (D) $96 \mathrm{~h}$ following treatment with different concentrations of $\mathrm{F} 2$ Data are expressed as means $\pm \mathrm{SD}(\mathrm{n}=4){ }^{* * *} \mathrm{P}<0.01$ and ${ }^{* * * *} \mathrm{P}<0.001$ indicate a significant reduction of cell viability in treated cells vs. control. Arrows $(\rightarrow)$ indicate that the cells were significantly revived. EN, eurycomanone; F2, Eurycoma longifolia extract.

$48 \mathrm{~h}$ following treatment (Fig. 5C). Following $96 \mathrm{~h}$ of $\mathrm{F} 2$ treatment, reductions in the proportion of TM3 cells in the $\mathrm{G}_{0} / \mathrm{G}_{1}$ phases treated with $0.1 \mathrm{mg} / \mathrm{ml} \mathrm{F} 2$ observed at 24,48 and $72 \mathrm{~h}$ time-points were reversed (Fig. 5E). Likewise, increments in the proportion of TM3 cells at the $\mathrm{S}$ phase treated with F2 observed at 24, 48 and $72 \mathrm{~h}$ were also reversed after $96 \mathrm{~h}$, particularly in cells treated with $0.1 \mathrm{mg} / \mathrm{ml} \mathrm{F} 2$ (Fig. 5E). The percentages of treated cells at the $G_{2}$ phase post $F 2$ treatment demonstrated no difference compared with those of control following F2 treatment for 24-96 h (Fig. 5).
Functional level of identified DEGs in F2-treated Leydig cells. Microarray analysis revealed 237 and 324 genes to be up- and downregulated, respectively, in Leydig cells $72 \mathrm{~h}$ following F2 treatment (Fig. 6A). However, the number of genes that were found to be up- and downregulated in Leydig cells was reduced to 192 and 212, respectively, 96 h following F2 treatment (Fig. 6A). These DEGs could indicate the mechanism on the revival of F2-treated Leydig cells and should be studied in depth to improve the understanding and safety of F2 consumption. A scatter plot was generated to assess the variations in 
A

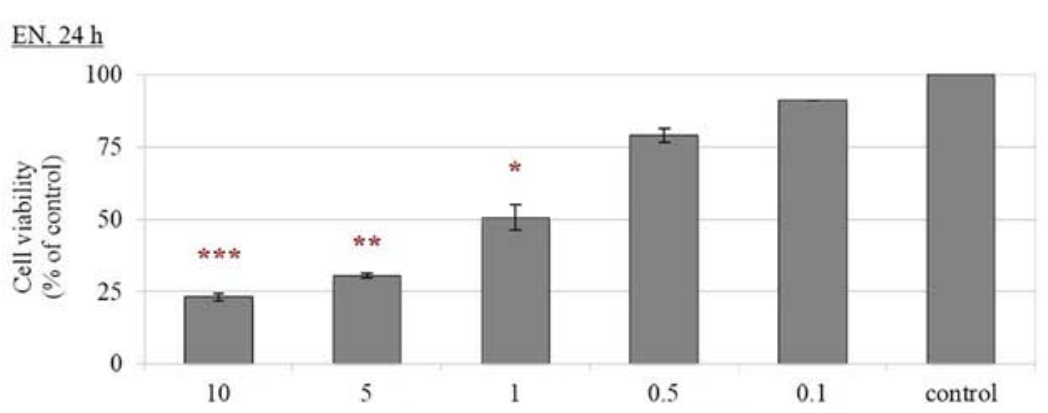

$B_{\text {EN. } 48 \text { h }}$

Treatment concentration $(\mu \mathrm{M})$

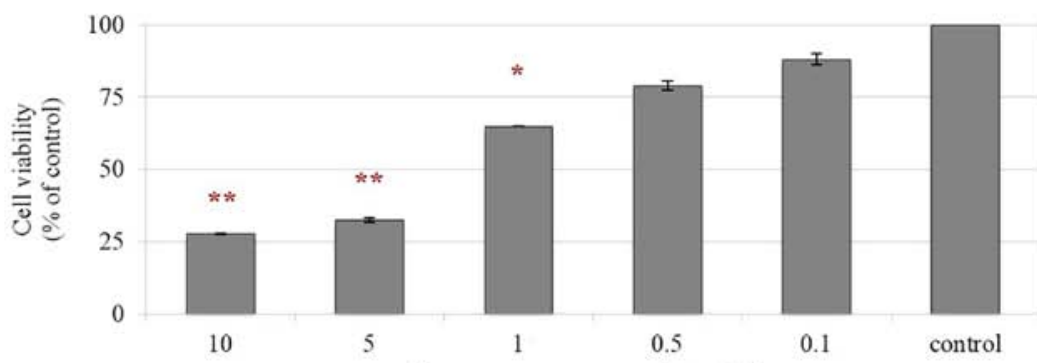

$C_{\text {EN. } 72 h}$

Treatment concentration $(\mu \mathrm{M})$

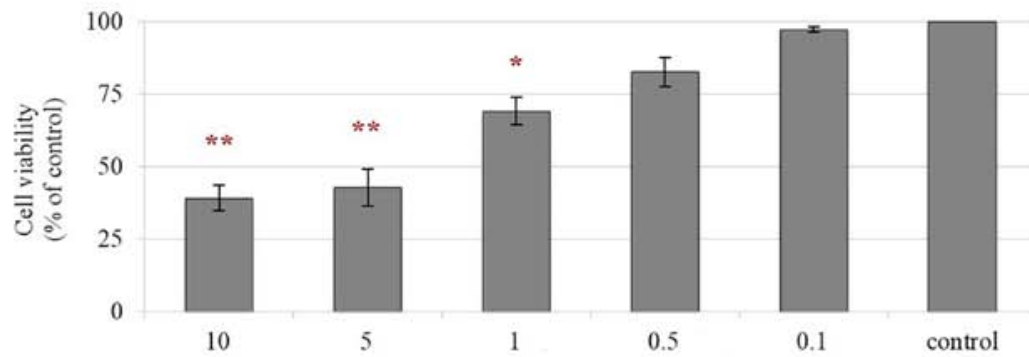

D EN.96h

Treatment concentration $(\mu \mathrm{M})$

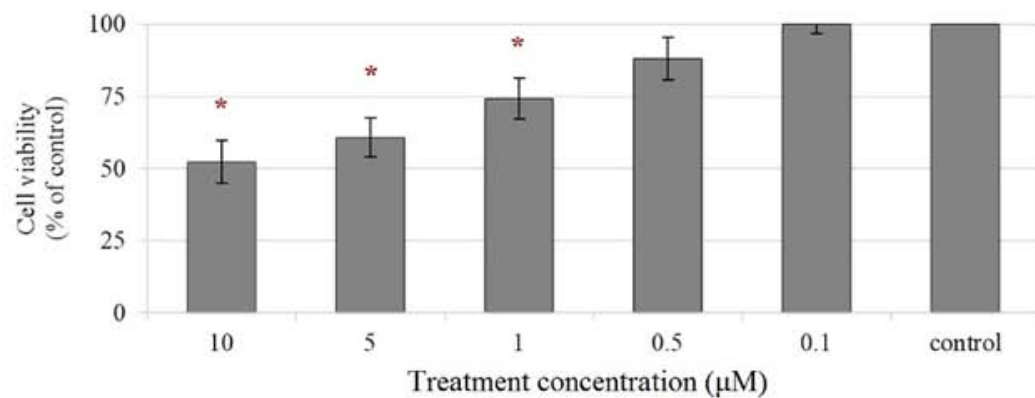

Figure 3. Effects of EN treatment on Leydig cell viability. Viability of TM3 cells was measured (A) 24, (B) 48, (C) 72 and (D) $96 \mathrm{~h}$ following treatment with different concentrations of EN. Data are expressed as means $\pm \mathrm{SD}(\mathrm{n}=4) .{ }^{*} \mathrm{P}<0.05,{ }^{* * *} \mathrm{P}<0.01$ and ${ }^{* * * *} \mathrm{P}<0.001$ indicate a significant reduction of cell viability in treated cells vs. control. EN, eurycomanone.

DEGs in the cyclin family, where its related members among non-treated (control) and F2-treated Leydig cells 72 and $96 \mathrm{~h}$ following treatment with F2 were compared (Fig. 6B). The DEGs in F2-treated Leydig cells were clearly observed in the plots, whereby the top 9 cyclin-related genes that demonstrated $>2$-fold up- and downregulated expression in F2-treated Leydig cells for 72 and $96 \mathrm{~h}$ were selected. Gene ontology of the DEGs revealed the role of the selected genes encoding the cyclin family of proteins and cyclin-dependent kinases (Table II). The selected genes, including cyclin-dependent kinase-like-3, cyclin G1, cyclin-dependent kinase inhibitor 1A (CDKN1A), cyclin L1, cyclin-dependent kinase-like 2 (CDKL2), heme oxygenase 1 , cyclin $\mathrm{G} 2$, cyclin B2 and cyclin-dependent kinase inhibitor $2 \mathrm{C}$ were then measured using RT-qPCR. The analysis revealed consistent expression of all 9 genes in Leydig cells treated with $0.1 \mathrm{mg} / \mathrm{ml} \mathrm{F} 2$ at all treatment time-points (Fig. 7). However, when $1.0 \mathrm{mg} / \mathrm{ml} \mathrm{F} 2$ was used for treatment, a significant reduction of CDKL2 expression was observed in Leydig cells treated for 72 and $96 \mathrm{~h}$ (Fig. 7E). The CDKL2 expression was reduced to $0.708(\mathrm{P}<0.05)$ and 0.743 $(\mathrm{P}<0.05)$ fold-change in Leydig cells treated with $1.0 \mathrm{mg} / \mathrm{ml}$ F2 for 72 and $96 \mathrm{~h}$, respectively, compared to the CDKL2 


\section{A}

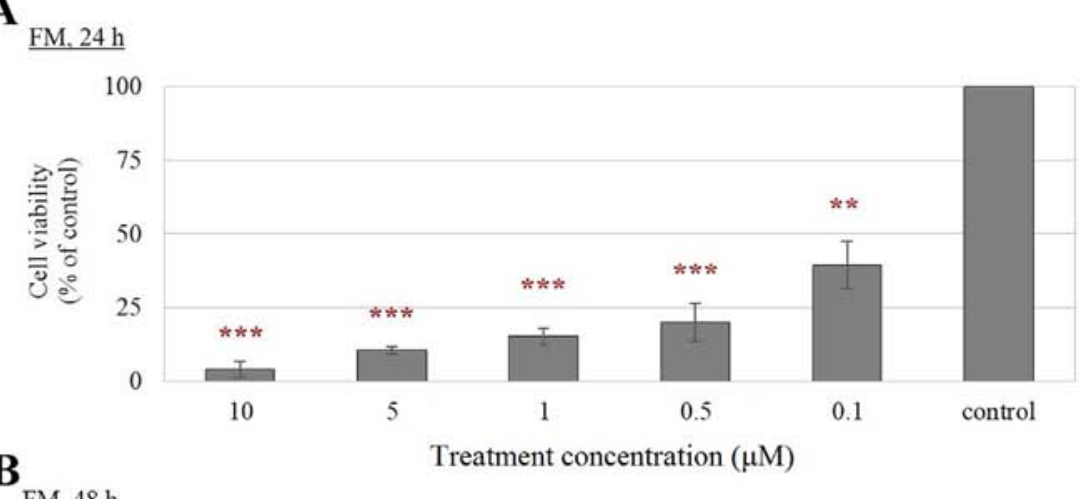

FM, 48 h

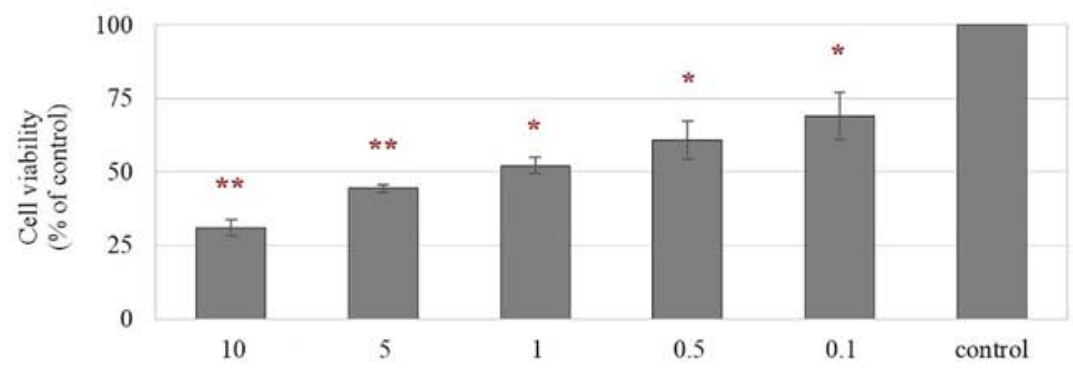

C

Treatment concentration $(\mu \mathrm{M})$

FM. $72 \mathrm{~h}$

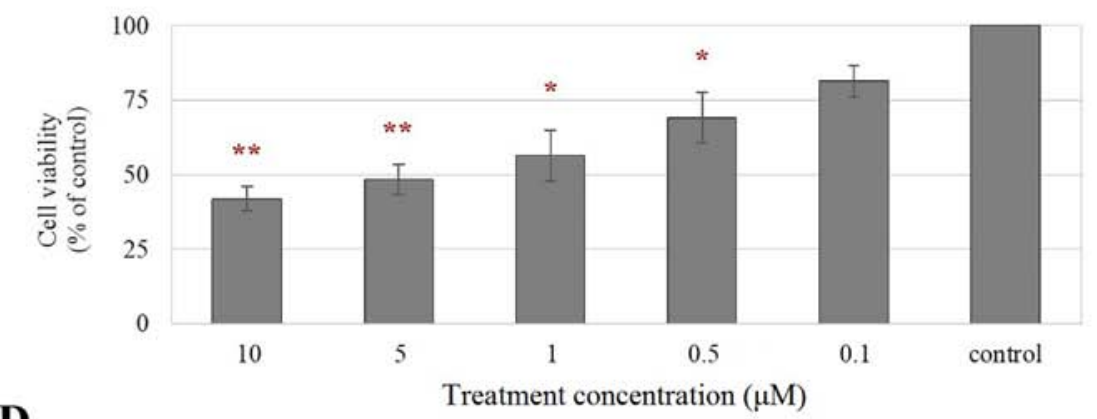

D

FM. $96 \mathrm{~h}$

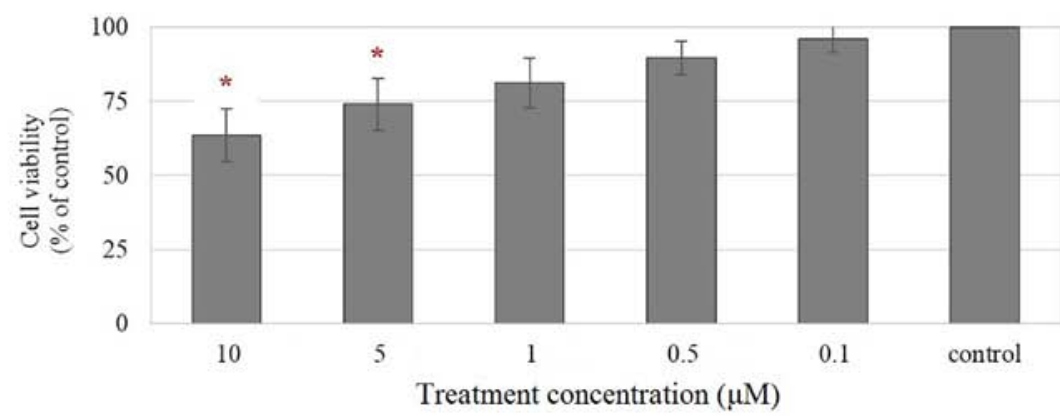

Figure 4. Effects of EN treatment on Leydig cell viability. Viability of TM3 cells was measured (A) 24, (B) 48, (C) 72 and (D) $96 \mathrm{~h}$ following treatment with different concentrations of FM. Data are expressed as means $\pm \mathrm{SD}(\mathrm{n}=4) .{ }^{*} \mathrm{P}<0.05,{ }^{* *} \mathrm{P}<0.01$ and ${ }^{* * * *} \mathrm{P}<0.001$ indicate a significant reduction of cell viability in treated cells vs. control. FM, formestane.

expression in $1.0 \mathrm{mg} / \mathrm{ml} \mathrm{F}$-treated Leydig cells for $24 \mathrm{~h}$ (1.000 fold-change). Comparison of the CDKL2 expression in the Leydig cells treated with $1.0 \mathrm{mg} / \mathrm{ml} \mathrm{F} 2$ (0.708 fold change; $\mathrm{P}<0.05)$ than that with $0.1 \mathrm{mg} / \mathrm{ml} \mathrm{F} 2$ (0.991 fold-change) for $72 \mathrm{~h}$ also showed significant reduction of the CDKL2 expression. Gene-gene interaction studies demonstrated that CDKL2 closely interacted with Casitas B-lineage lymphoma (CBL) and sphingosine kinase 1-interactor-A-kinase adaptor protein domain-containing (Sphkap), which may also serve important roles in the mechanism and action of cell revival in F2-treated Leydig cells (Fig. 8).

\section{Discussion}

The importance of exploiting naturally occurring medicines from herbal plants has been growing around the world. An increasing number of studies are recognising the use of herbal medicine for therapy due to fewer side effects, 
A
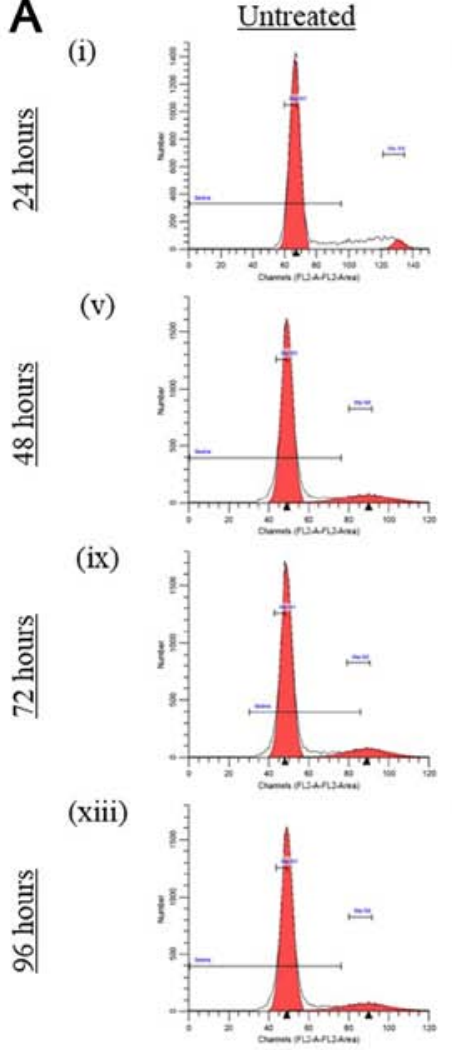

(ii)

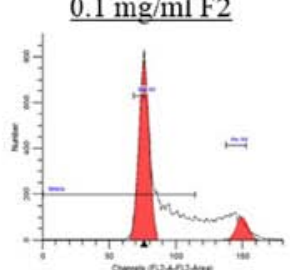

(vi)

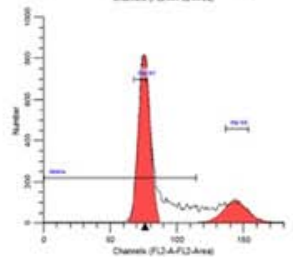

(x)

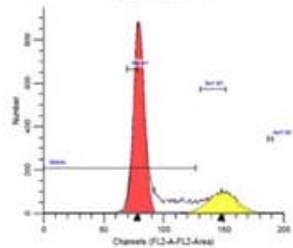

(xiv)

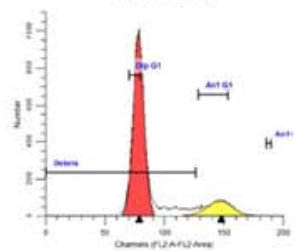

(iii)

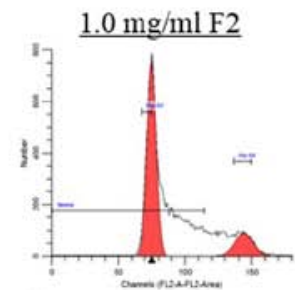

(vii)

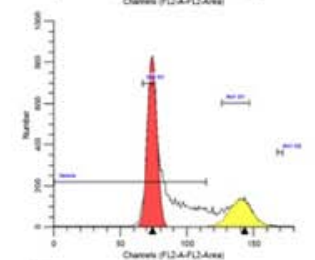

(xi)

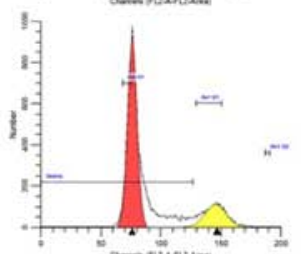

(xv)

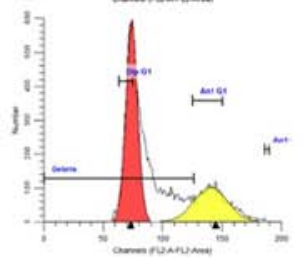

(iv)

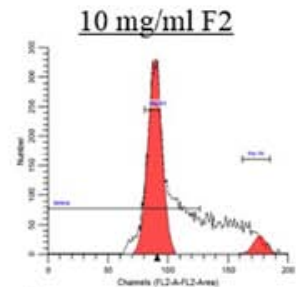

(viii)

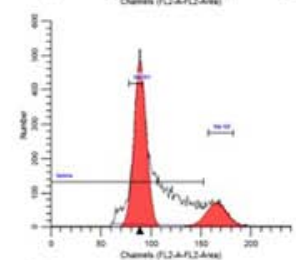

(xii)

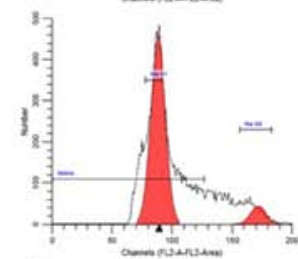

(xvi)

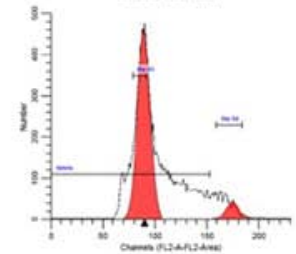

B $22.24 \mathrm{~h}$

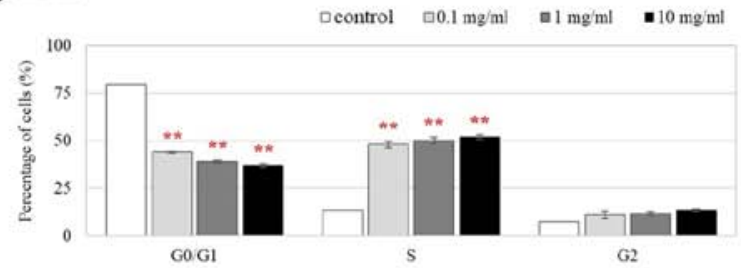

D $\mathrm{E2} .72 \mathrm{~h}$

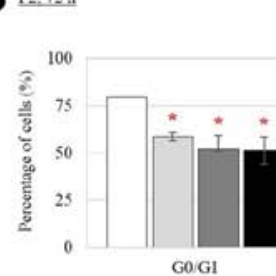

Dcontrol $\quad 00.1 \mathrm{mg} / \mathrm{ml} \quad=1 \mathrm{mg} \mathrm{ml} \quad$ - $10 \mathrm{mg} \mathrm{ml}$

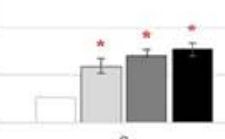

C $22.48 \mathrm{~h}$

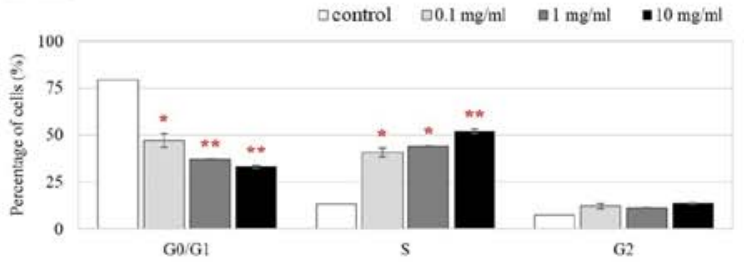

E $\quad 22.96 \mathrm{~h}$

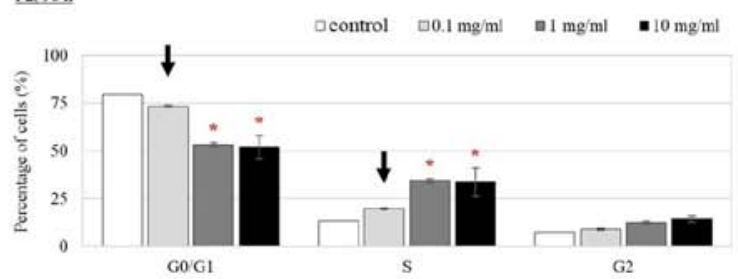

Figure 5. Cell cycle distribution of Leydig cells after F2 treatment. (A) Histograms of cell cycle distribution. (i) Untreated Leydig cells (control), Leydig cells treated with (ii) $0.1 \mathrm{mg} / \mathrm{ml} \mathrm{F}$, (iii) $1.0 \mathrm{mg} / \mathrm{ml} \mathrm{F}$, and (iv) $10 \mathrm{mg} / \mathrm{ml} \mathrm{F} 2$ for $24 \mathrm{~h}$; (v) Untreated Leydig cells (control), Leydig cells treated with (vi) $0.1 \mathrm{mg} / \mathrm{ml}$ F2, (vii) $1.0 \mathrm{mg} / \mathrm{ml} \mathrm{F2}$, and (viii) $10 \mathrm{mg} / \mathrm{ml} \mathrm{F2}$ for $48 \mathrm{~h}$; (ix) Untreated Leydig cells (control), Leydig cells treated with (x) $0.1 \mathrm{mg} / \mathrm{ml} \mathrm{F}$, (xi) $1.0 \mathrm{mg} / \mathrm{ml} \mathrm{F2,}$ and (xii) $10 \mathrm{mg} / \mathrm{ml} \mathrm{F} 2$ for $72 \mathrm{~h}$; (xiii) Untreated Leydig cells (control), Leydig cells treated with (xiv) $0.1 \mathrm{mg} / \mathrm{ml} \mathrm{F} 2$, (xv) $1.0 \mathrm{mg} / \mathrm{ml} \mathrm{F}$, and (xvi) $10 \mathrm{mg} / \mathrm{ml} \mathrm{F2}$ for $96 \mathrm{~h}$. Quantification of cell cycle distribution (B) 24, (C) 48, (D) 72 and (E) $96 \mathrm{~h}$ after F2 treatment. Data are expressed as means $\pm \mathrm{SD}(\mathrm{n}=3$ ). $\mathrm{P}<0.05$ and ${ }^{* *} \mathrm{P}<0.01$ indicate a significant change of cell cycle phase in treated cells vs. control at specific time-points. Arrows $(\rightarrow)$ indicate the cells were significantly revived. F2, Eurycoma longifolia extract.

environmentally-friendly and increased cost-effectiveness $(1,31,32)$. Previous studies by Low et al $(8,26)$ revealed that quassinoid (EN) found in E. longifolia increased testosterone levels in male rats testicular Leydig cell-rich interstitial cells. However, the scientific evidence for the mechanism behind this phenomenon remains unknown. The present study demonstrated that Leydig cells treated with F2, EN and FM exhibited higher levels of testosterone in the culture supernatants. F2 acted as a potential testosterone booster because induction could also be achieved at lower concentrations $(0.1 \mathrm{mg} / \mathrm{ml})$ according to results in the in vitro assays. Although F2 treatment did not affect the accumulated testosterone level, treatment of Leydig cells with as little as $0.1 \mathrm{mg} / \mathrm{ml} \mathrm{F} 2$ reduced the viability of the treated cells. A previous study revealed that the treatment of a rat cell suspension at doses $0.1-10 \mu \mathrm{M}$ EN demonstrated non-cytotoxicity to the cells; $>95 \%$ cell viability remained (26). The cell suspension contained $\sim 40 \%$ Leydig cells with a viability of $>97 \%$. However, the effect of 
Table II. Top nine selected genes showing $>2$-fold up- and downregulation by microarray analysis. The Leydig cells were treated with $0.1 \mathrm{mg} / \mathrm{ml} \mathrm{F} 2$ for 72 and $96 \mathrm{~h}$.

\begin{tabular}{|c|c|c|c|c|}
\hline No. & Gene name & $72 \mathrm{~h}$ (fold) & $96 \mathrm{~h}$ (fold) & Gene function \\
\hline 1 & $\begin{array}{l}\text { Cyclin-dependent } \\
\text { kinase like-3 }\end{array}$ & 2.204 & 1.959 & $\begin{array}{l}\text { A member of the cyclin family that encodes a CMGC-type } \\
\text { serine/threonine protein kinase for an unknown function. }\end{array}$ \\
\hline 2 & Cyclin G1 & 2.189 & 2.114 & $\begin{array}{l}\text { A transcriptional target of p53 and is induced by DNA damage in a } \\
\text { p53 dependent manner. }\end{array}$ \\
\hline 3 & $\begin{array}{l}\text { Cyclin-dependent kinase } \\
\text { inhibitor } 1 \mathrm{~A}\end{array}$ & 3.531 & 3.249 & $\begin{array}{l}\text { Encodes a potent cyclin-dependent kinase inhibitor that } \\
\text { binds to and inhibits the activity of cyclin-cyclin-dependent } \\
\text { kinase } 2 \text { or -cyclin-dependent kinase } 4 \text { complexes. A regulator of } \\
\text { cell cycle progression at } G_{1} \text {. }\end{array}$ \\
\hline 4 & Cyclin L1 & 2.056 & 1.959 & $\begin{array}{l}\text { A regulatory subunit of CDK11 and involved in splicing process for } \\
\text { mRNA production. }\end{array}$ \\
\hline 5 & $\begin{array}{l}\text { Cyclin-dependent } \\
\text { kinase-like } 2\end{array}$ & 2.085 & 1.647 & $\begin{array}{l}\text { A member of a large family of CDC2-related } \\
\text { serine/threonine protein kinases. }\end{array}$ \\
\hline 6 & Heme oxygenase 1 & 3.758 & 3.424 & $\begin{array}{l}\text { An enzyme that catalyzes the degradation of heme to } \\
\text { produce biliverdin, ferrous iron and carbon monoxide. }\end{array}$ \\
\hline 7 & Cyclin G2 & -2.479 & -2.235 & $\begin{array}{l}\text { Contains a C-terminal PEST protein destabilization motif, suggesting } \\
\text { that their expression is tightly regulated through the cell cycle. }\end{array}$ \\
\hline 8 & Cyclin B2 & -2.219 & -1.424 & $\begin{array}{l}\text { A member of the cyclin family that regulate PLK } 1 \text { activity } \\
\text { at } \mathrm{G}_{2} / \mathrm{M} \text { Transition. }\end{array}$ \\
\hline 9 & $\begin{array}{l}\text { Cyclin-dependent kinase } \\
\text { inhibitor } 2 \mathrm{C}\end{array}$ & -1.866 & -2.189 & $\begin{array}{l}\text { A protein coding gene for the member of the INK } 4 \\
\text { family that contains } 5 \text { ankyrin repeats. }\end{array}$ \\
\hline
\end{tabular}

F2, Eurycoma longifolia extract; CDK, cyclin-dependent kinase; CDC2, cyclin-dependent kinase 1; polo-like kinase 1; INK4, cyclin-dependent kinase inhibitor $2 \mathrm{~A}$.
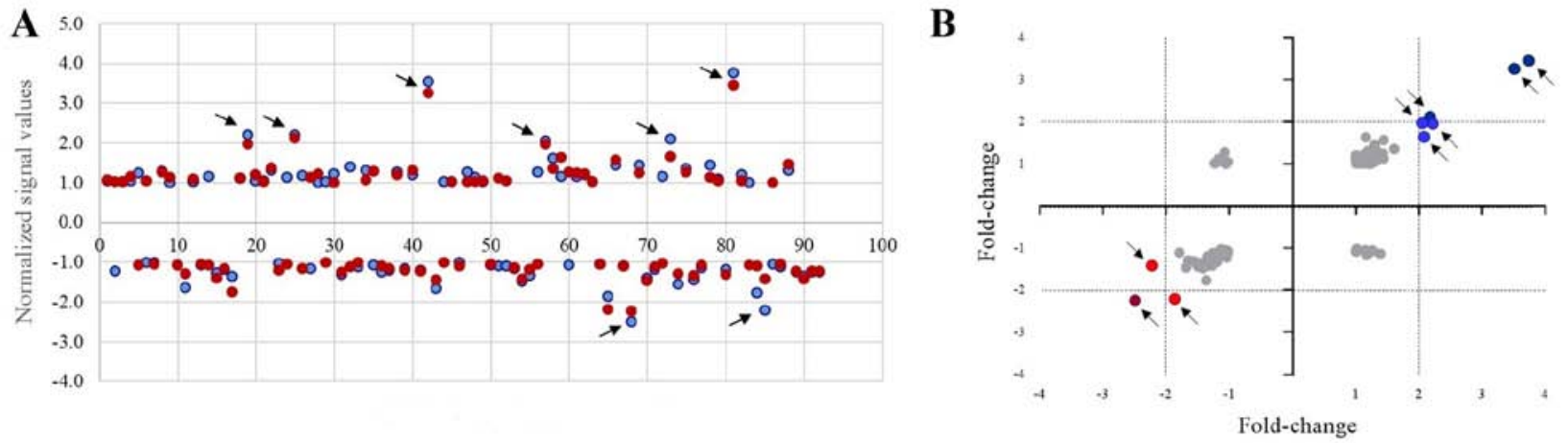

Figure 6. Analysis of differentially expressed genes in Leydig cells following F2 treatment. (A) One-dimensional and (B) two-dimensional scatter plots for differentially expressed genes in F2-treated Leydig cells. The cells were treated with $0.1 \mathrm{mg} / \mathrm{ml} \mathrm{F} 2$ for 72 and $96 \mathrm{~h}$. The x-axis presents the gene distribution, and the $y$-axis presents the average normalized signal values of each gene in treated and non-treated cells (control). The blue and red dots indicate the normalized gene signal values in F2-treated cells compared with controls after 72 and $96 \mathrm{~h}$, respectively. The deeper shades of blue or red dots represent higher magnitudes of differential expression. Arrows $(\rightarrow$ ) indicate significant up- or downregulated genes. F2, Eurycoma longifolia extract.

F2 on the viability of the cell suspension was not mentioned in this previous study (26). The present study revealed that high viability (>95\%) of EN-treated cells was only observed when lower concentrations of $\mathrm{EN}(<0.5 \mu \mathrm{M})$ were used. By contrast, a 50\% reduction in cell viability was found when higher concentrations of EN were used. The current formulation of $\mathrm{F} 2$ contains $7.46 \% \mathrm{EN}$, which may be a factor to consider in future formulations of $\mathrm{F} 2$, which should contain $\leq 0.5 \mu \mathrm{M}$ EN to reduce the inhibitory effect of $\mathrm{F} 2$ on Leydig cells (33). The reduction of cell viability could be attributed to the biologically active components in F2 (13,21-dihydroeurycomanone, $13 \alpha(21)$-epoxyeurycomanone or eurycomanol) that have been previously found to inhibit cell replication, division and proliferation, in turn terminating the growth of the treated cells.

Cell cycle is a continuously organised process during which replication and division of a cell occurs. The primary principle of cell cycle assays is to quantify the cellular DNA content at each phase of the cycle (34). PI, which binds to the DNA of the cell and produces a fluorescent signal, has been 
A

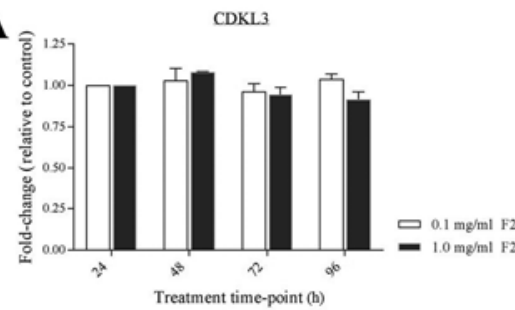

D

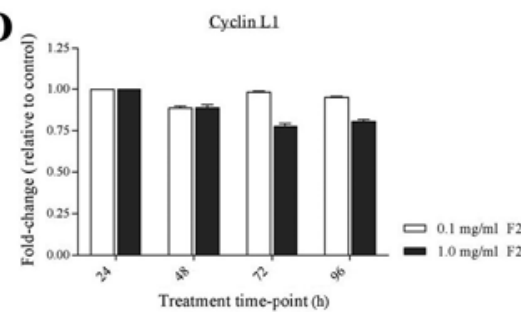

G

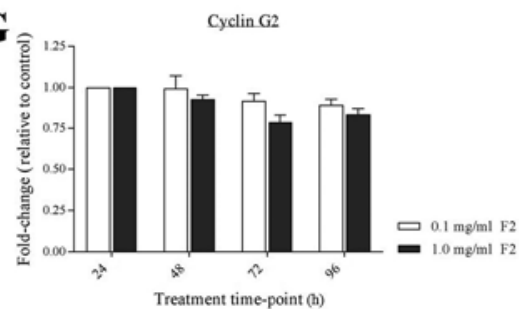

B

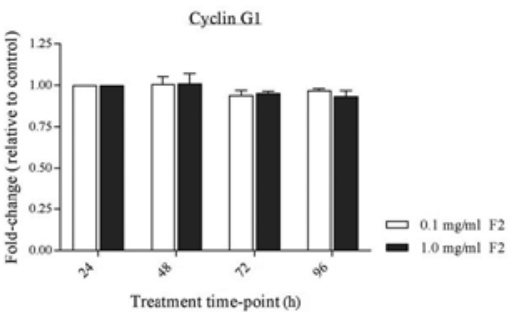

E

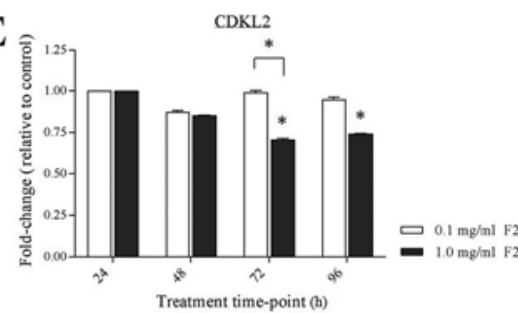

H

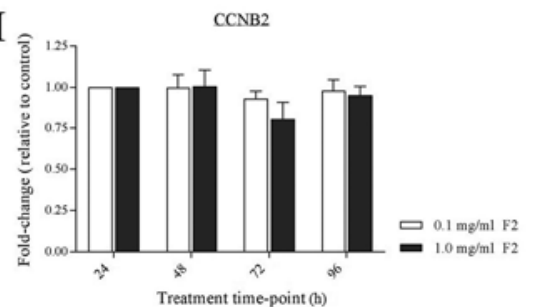

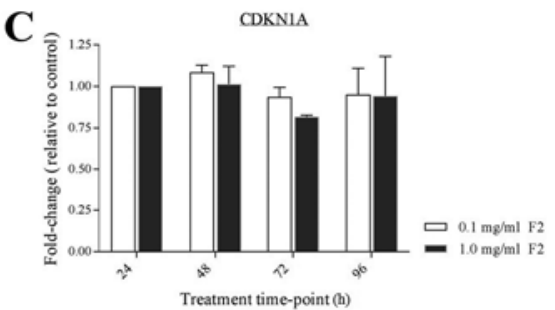

F

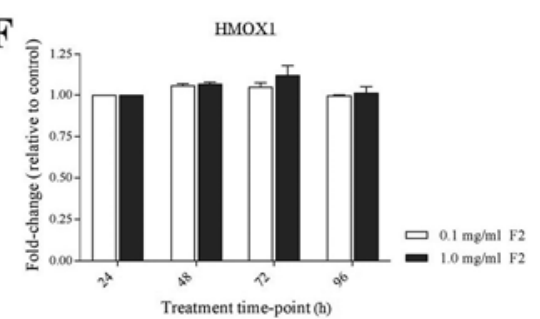

I

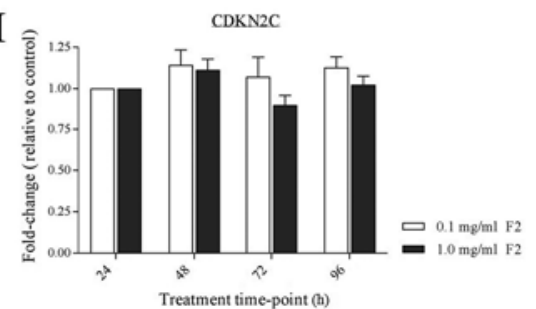

Figure 7. Gene expression validation in F2-treated Leydig cells. (A) CDKL3, (B) Cyclin G1, (C) CDKN1A, (D) Cyclin L1, (E) CDKL2, (F) HMOX1, (G) Cyclin G2, (H) CCNB2 and (I) CDNK2C mRNA expression in TM3 cells were measured after F2 treatment. Data are expressed as means \pm SD ( $=3$ ). ${ }^{*} \mathrm{P}<0.05$ indicates a significant fold-change of Leydig cells treated with $1.0 \mathrm{mg} / \mathrm{ml} \mathrm{F} 2$ after specific time-point vs. the same treated cells after $24 \mathrm{~h}$ or vs. the cells treated with $0.1 \mathrm{mg} / \mathrm{ml} \mathrm{F} 2$ after the same time-point. CDKL3, cyclin-dependent kinase-like-3; CDKN1A, cyclin-dependent kinase inhibitor 1A; CDKL2, cyclin-dependent kinase-like 2; HMOX1, heme oxygenase 1; CCNB2, cyclin B2; CDKN2C, cyclin-dependent kinase inhibitor 2C.

used extensively for cell cycle analyses (34). The cell cycle consists of two major phases; interphase (90\%) and mitosis (10\%) (34). The interphase can be divided further into another three sub-phases, which are $G_{0} / G_{1}, S$ and $G_{2}$, and the mitotic phase, which is broken down further into mitosis and cytokinesis (35). The present study revealed that Leydig cells treated with $\mathrm{F} 2$ demonstrated reductions in cell viability by reducing the cell population in the $G_{0} / G_{1}$ phase, which could have been caused by cell cycle arrest at the $S$ phase. However, cell viability was revived, especially following $96 \mathrm{~h}$ treatment with F2, which may be due to changes in the number of cells at the $\mathrm{G}_{0} / \mathrm{G}_{1}$ and $\mathrm{S}$ phases. Following $96 \mathrm{~h}$ treatment with $0.1 \mathrm{mg} / \mathrm{ml} \mathrm{F} 2$, the proportions of Leydig cells at the $\mathrm{G}_{0} / \mathrm{G}_{1}$ and $S$ phases were not found to be significantly different compared with those of the control cells. The cell revival may also be attributed to the reduced drug effect and adaptation of cells to F2 treatment. Therefore, further identification of the potential molecular target(s) that regulate this mechanism is warranted.

A number of studies have previously demonstrated cell cycle arrest at the $\mathrm{S}$ phase upon treatment of Leydig cells with different compounds (36-38). A study recently investigated the effects of calretinin on the testicular Leydig cell line, MLTC-1, whereby cell cycle analysis demonstrated a significantly high cell number at the $\mathrm{S}$ phase, suggesting that the reduction in cell viability was due to S-phase cell cycle arrest (36). Similarly, a study conducted a cell cycle test by using primary Leydig cells treated with different concentrations of dehydroepiandrosterone (DHEA) and discovered that after $48 \mathrm{~h} 50 \mu \mathrm{M}$ DHEA treatment, the cell number at $\mathrm{S}$ phase was significantly increased following a reduction in the cell number at the $\mathrm{G}_{2}$ phase compared to that in the control group (37). These observations indicate that cell cycle arrest in $\mathrm{S}$ phase inhibited the growth of Leydig cells. To the best of our knowledge, only two articles have reported the effect of E. longifolia extracts on the cell cycle progression. Tong et al (38) previously reported that a standardised E. longifolia extract, SQ40, could inhibit LNCaP cell development by suppressing cell growth via $G_{0} / G_{1}$ phase arrest accompanied by downregulation of cyclin dependant kinase (CDK)2, CDK4, Cyclin D1 and Cyclin D3 expression and the upregulation in the protein level of p21CDKN1A. By contrast, Al-Salahi et al (39) demonstrated that TAF273 from the E. longifolia root methanolic extract exerted a potent cytotoxic effect on K562 cells via cell cycle arrest at the $G_{1}$ and $S$ phases. In the present study, the ability of $\mathrm{F} 2$ to regain the cell population at the $G_{0} / G_{1}$ phase could be attributed to the revival of the F2-treated Leydig cells following $96 \mathrm{~h}$ of treatment. Therefore, it is reasonable to suggest that the $G_{0} / G_{1}$ and $\mathrm{S}$ phases are the critical factors to explore in improving the viability of F2-treated Leydig cells.

At the molecular level, CDKL2 expression was found to be significantly affected in Leydig cells treated with $1.0 \mathrm{mg} / \mathrm{ml}$ F2 for 72 and $96 \mathrm{~h}$ compared with that of respective controls, implying the essential role of CDKL2 in regulating the viability of F2-treated Leydig cells. However, the detection of CDKL2 expression does not clearly define the mechanisms that were being studied. The CDKL2 expression profiles in Leydig cells treated with 0.1 and $1.0 \mathrm{mg} / \mathrm{ml} \mathrm{F} 2$ for 72 and $96 \mathrm{~h}$ did not clearly reveal the mechanisms of S-phase cell cycle arrest and reduced cell 


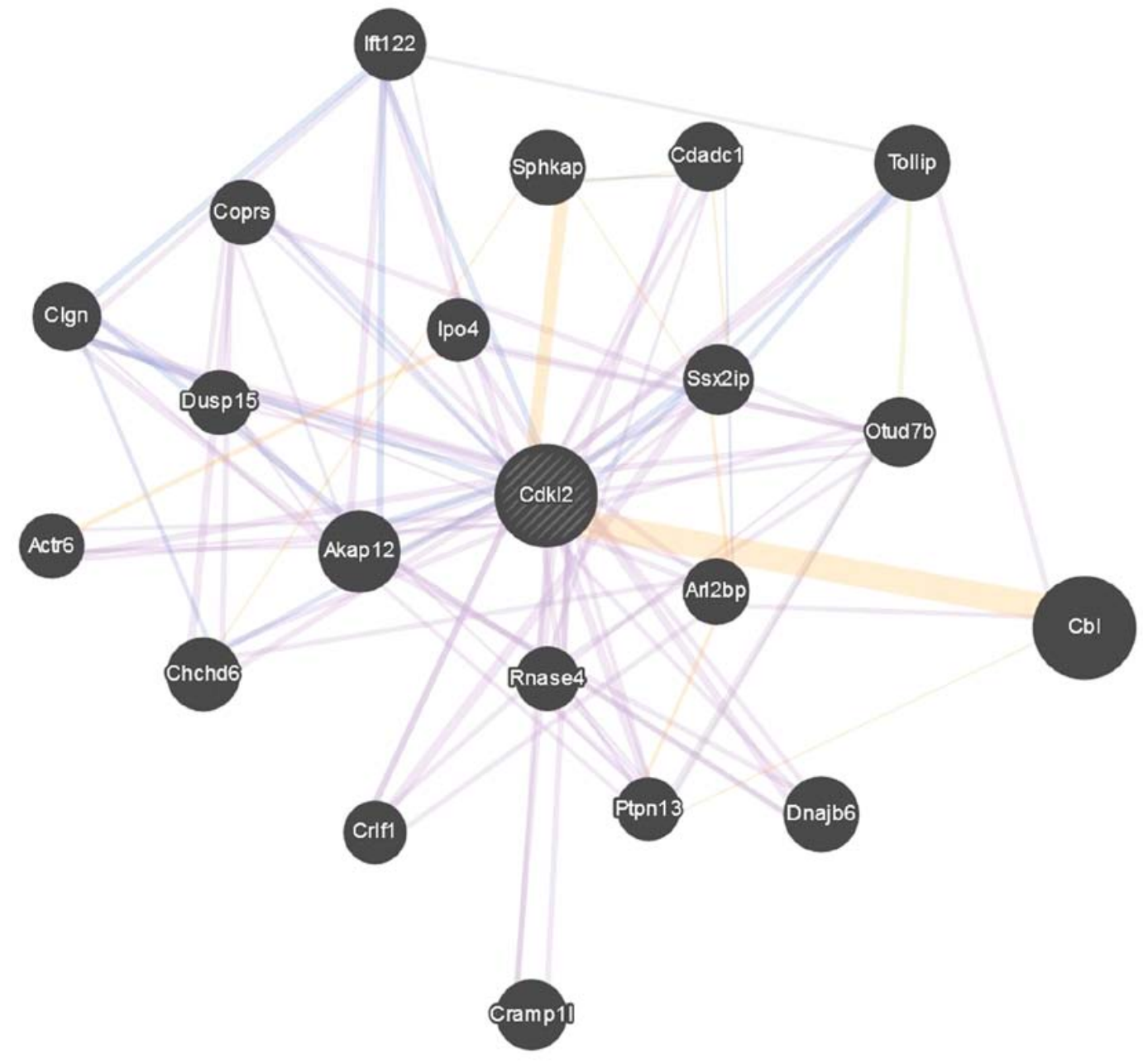

Figure 8. Prediction of potential genes associated with CDKL2 using the GeneMANIA Cytoscape program v.3.6.0 (https://genemania.org/). The genes are shown in circles, and the lines reflect the interrelatedness of genes. The relevance detection algorithms assign the circle size and the line thickness in each individual gene network. Orange, purple, blue and grey lines indicate prediction, co-expression, co-localization and others, respectively. CDKL2, cyclin-dependent kinase-like 2.

viability in the cells. Leydig cells treated with $\leq 1.0 \mathrm{mg} / \mathrm{ml} \mathrm{F} 2$ for $72 \mathrm{~h}$ were not revived compared with those treated with the same concentrations of F2 for $96 \mathrm{~h}$, which started to revive. In addition, the populations of Leydig cells treated with $0.1 \mathrm{mg} / \mathrm{ml} \mathrm{F} 2$ for $96 \mathrm{~h}$ in $\mathrm{G}_{0} / \mathrm{G}_{1}$ and $\mathrm{S}$ phases of the cell cycle were not significantly different compared with those of the respective controls, indicative of cell revival. Compared with the populations of Leydig cells treated with $1.0 \mathrm{mg} / \mathrm{ml} \mathrm{F} 2$ for $96 \mathrm{~h}$ at the $\mathrm{G}_{0} / \mathrm{G}_{1}$ and $\mathrm{S}$ phases of the cell cycle, there was a significant difference compared with those of the respective controls. CDKL2 is a cdc2-related serine/threonine protein kinase that is postnatally expressed in various brain regions, including the cerebral cortex, entorhinal cortex, hippocampus, amygdala and dorsal thalamus (40). The upregulation of CDKL2 in these regions suggests that it has a role in cognition and emotion. Although studies have elucidated the physiological role of CDKL2 in mice models lacking $C d k l 2$, detailed studies on $C d k l 2$ remain rare. CDKL2 may also be involved in gastric cancer progression, where a previous study exploring the clinical effect of CDKL2 on gastric cancer indicated that the loss of CDKL2 was positively associated with several clinical and pathological characteristics (40-42). Patients with low CDKL2 expression levels exhibited significantly worse disease-free and overall survival rates compared with those with high CDKL2 expression levels (41). Cellular studies revealed that CDKL2 overexpression impaired the proliferation and invasion of gastric cancer cells (41); therefore, the loss of CDKL2 may serve as a biomarker for predicting the outcome in patients with gastric cancer and is a potential therapeutic target for gastric cancer treatment. To the best of our knowledge, only one study has previously demonstrated that the expression of CDKL2 was upregulated in human breast cancer tissues and cells compared with that in normal breast tissues and cells (43).

CDKL2 is similar to another member of the cyclin-dependent kinase family, CDKL1, and is presumably derived from an early vertebrate duplication (41). Reanalysis of genome-wide association studies suggested that CDKL2 may contribute to breast cancer, where human mammary gland epithelial cells expressing CDKL2 demonstrated increased epithelial-mesenchymal transition and stem cell properties, which were obtained from the activation of a positive feedback loop comprising of Zinc finger E-box-binding homeobox 1, E-cadherin and $\beta$-catenin (43). In addition, CDKL2 promoted xenograft proliferation and metastasis in vivo $(41,43)$. In particular, CDKL2 expression was found to be upregulated in mesenchymal breast cancer cells compared with that in epithelial cells, where its upregulation is negatively associated with 
disease-free survival $(41,43)$. The present study demonstrated that the reduced growth of Leydig cells following treatment with high concentrations of F2 may be due to the downregulation of CDKL2 expression. Therefore, further investigation on the regulation of this specific molecular target and its associated targets, such as CBL and Sphkap, which may act in concert with CDKL2 in F2-treated Leydig cells, is warranted.

In conclusion, the present study demonstrated the elevation of testosterone production in Leydig cells treated with the standardised E. longifolia extract, F2. However, this phenomenon was accompanied by the reduced viability of treated cells. Also, the present study revealed CDKL2 as an important molecular target for the regulation of these F2-dependent mechanisms. However, further studies are warranted to improve understanding of the growth inhibitory effect caused by F2 treatment in Leydig cells.

\section{Acknowledgements}

Not applicable.

\section{Funding}

Universiti Sains Malaysia Fellowship Scheme supported Nor Amira Khurshid Ahmed (grant no. P-NFM0006/16R). The present study was supported by the Ministry of Agriculture and Agro-based Industry, Malaysia, under the National Key Economic Areas (NKEA) Research Grant Scheme (grant no. 304/PFARMASI/650733/k123).

\section{Availability of data and materials}

The datasets used and/or analysed during the current study are available from the corresponding author on reasonable request.

\section{Authors' contributions}

HS and CL contributed to the conception of the present study. LY, KY and CL made substantial contributions to the design of the present study. NA and LK performed the experiments under technical support provided by GP, HS and CL. NA, GP and $\mathrm{KY}$ interpreted the results, drafted and revised the manuscript. All authors read and approved the final manuscript.

\section{Ethics approval and consent to participate}

Not applicable.

\section{Patient consent for publication}

Not applicable.

\section{Competing interests}

The authors declare that they have no competing interests.

\section{References}

1. Ekor M: The growing use of herbal medicines: Issues relating to adverse reactions and challenges in monitoring safety. Front Pharmacol 4: 177, 2014
2. Nasri H, Baradaran A, Shirzad H and Rafieian-Kopaei M: New concepts in nutraceuticals as alternative for pharmaceuticals. Int J Prev Med 5: 1487-1499, 2014.

3. Rehman SU, Choe K and Yoo HH: Review on a traditional herbal medicine, Eurycoma longifolia Jack (Tongkat Ali): Its traditional uses, chemistry, evidence-based pharmacology and toxicology Molecules 21: 331, 2016.

4. Yuan H, Ma Q, Ye L and Piao G: The traditional medicine and modern medicine from natural products. Molecules 21: 559, 2016.

5. Chan KL, Choo CY, Morita H and Itokawa H: High performance liquid chromatography in phytochemical analysis of Eurycoma longifolia. Planta Med 64: 741-745, 1998.

6. Chan KL, Low BS, Teh CH and Das PK: The effect of Eurycoma longifolia on sperm quality of male rats. Nat Prod Commun 4: 1331-1336, 2009.

7. Meng D, Li X, Han L, Zhang L, An W and Li X: Four new quassinoids from the roots Eurycoma longifolia jack. Fitoterapia 92: 105-110, 2014.

8. Low BS, Das PK and Chan KL: Standardized quassinoid-rich Eurycoma longifolia extract improved spermatogenesis and fertility in male rats via the hypothalamic-pituitary-gonadal axis. J Ethnopharmacol 145: 706-714, 2013

9. Mohamed AN, Vejayan J and Yusoff MM: Review on Eurycoma longifolia pharmacological and phytochemical properties. J Appl Sci 15: 831-844, 2015.

10. Farouk AE and Benafri A: Antibacterial activity of Eurycoma longifolia Jack. A Malaysian medicinal plant. Saudi Med J 28: 1422-1424, 2007.

11. Nurhanan MY, Azimahtol Hawariah LP, Mohd Ilham A and Mohd Shukri MA: Cytotoxic effects of the root extracts of Eurycoma longifolia Jack. Phytother Res 19: 994-996, 2005.

12. Wernsdorfer WH, Ismail S, Chan KL, Congpuong $\mathrm{K}$ and Wernsdorfer G: Activity of Eurycoma longifolia root extract against plasmodium falciparum in vitro. Wien Klin Wochenschr 121 (Suppl 3): S23-S26, 2009.

13. Chuen CS and Azimahtol HLP: Eurycomanone exerts antiproliferative activity via apoptosis upon MCF-7 cells. In: Proceedings of the 4th Annual Seminar of National Science Fellowship, BIO04, 2004.

14. Kuo PC, Damu AG, Lee KH and Wu TS: Cytotoxic and antimalarial constituents from the roots of Eurycoma longifolia. Bioorg Med Chem 12: 537-544, 2004.

15. Noor MM, Mohd Nor AHS and Hassan LC: The effect of Eurycoma longifolia Jack (Tongkat Ali) on sexual behaviour and sperm quality in rats. Malaysia J Pharm Sci 2: 53-60, 2004.

16. Park S, Nhiem NX, Kiem PV, Minh CV, Tai BH, Kim N, Yoo HH, Song JH, Ko HJ and Kim SH: Five new quassinoids and cytotoxic constituents from the roots of Eurycoma longifolia. Bioorg Med Chem Lett 24: 3835-3840, 2014.

17. Ang HH, Ikeda S and Gan EK: Evaluation of the potency activity of aphrodisiac in Eurycoma longifolia jack. Phytother Res 15: 435-436, 2001.

18. Shuid AN, El-arabi E, Effendy NM, Razak HS, Muhammad N, Mohamed N and Soelaiman IN: Eurycoma longifolia upregulates osteoprotegerin gene expression in androgen-deficient osteoporosis rat model. BMC Complement Altern Med 12: 152, 2012.

19. Zhari I, Norhayati I and Jaafar L: Malaysian herbal monograph. Malaysian Monograph Committee 1: 67-70, 1999.

20. Bhat R and Karim AA: Tongkat ali (Eurycoma longifolia Jack): A review on its ethnobotany and pharmacological importance. Fitoterapia 81: 669-679, 2010.

21. Foley GL: Overview of male reproductive pathology. Toxicol Pathol 29: 49-63, 2001.

22. Erasmus N, Solomon MC, Fortuin KA and Henkel RR: Effect of Eurycoma longifolia Jack (Tongkat Ali) extract on human spermatozoa in vitro. Andrologia 44: 308-314, 2012.

23. Isidori AM, Buvat J, Corona G, Goldstein I, Jannini EA, Lenzi A, Porst H, Salonia A, Traish AM and Maggi M: A critical analysis of the role of testosterone in erectile function: From pathophysiology to treatment-a systematic review. Eur Urol 65: 99-112,2014.

24. Talbott SM, Talbott JA, George A and Pugh M: Effect of Tongkat Ali on stress hormones and psychological mood state in moderately stressed subjects. J Int Soc Sports Nutr 10: 28, 2013.

25. Miyake K, Tezuka Y, Awale S, Li F and Kadota S: Quassinoids from Eurycoma longifolia. J Nat Prod 72: 2135-2140, 2009.

26. Low BS, Choi SB, Abdul Wahab H, Das PK and Chan KL: Eurycomanone, the major quassinoid in Eurycoma longifolia root extract increases spermatogenesis by inhibiting the activity of phosphodiesterase and aromatase in steroidogenesis. J Ethnopharmacol 149: 201-207, 2013. 
27. Solomon MC, Erasmus $\mathrm{N}$ and Henkel RR: In vivo effects of Eurycoma longifolia Jack (Tongkat Ali) extract on reproductive functions in the rat. Andrologia 46: 339-348, 2014.

28. Jayusman PA, Mohamed IN, Alias E, Mohamed N and Shuid AN: The effects of quassinoid-rich Eurycoma longifolia extract on bone turnover and histomorphometry indices in the androgen-deficient osteoporosis rat model. Nutrients 10: 799, 2018.

29. Livak KJ and Schmittgen TD: Analysis of relative gene expression data using real-time quantitative PCR and the 2(-Delta Delta C(T)) method. Methods 25: 402-408, 2001.

30. The Gene Ontology Consortium: The gene ontology resource: 20 years and still GOing strong. Nucleic Acids Res 47: D330-D338, 2019.

31. Fokunang CN, Ndikum V, Tabi OY, Jiofack RB, Ngameni B, Guedje NM, Tembe-Fokunang EA, Tomkins P, Barkwan S, Kechia F, et al: Traditional medicine: Past, present and future research and development prospects and integration in the national health system of cameroon. Afr J Tradit Complement Altern Med 8: 284-295, 2011.

32. Wachtel-Galor S and Benzie IFF (eds): Herbal medicine: An introduction to its history, usage, regulation, current trends, and research needs. In: Herbal Medicine: Biomolecular and Clinical Aspects. 2nd edition. CRC Press /Taylor \& Francis, Boca Raton, FL, 2011.

33. Thu HE, Hussain Z, Mohamed IN and Shuid AN: Eurycoma longifolia, a promising suppressor of RANKL-induced differentiation and activation of osteoclasts: An in vitro mechanistic evaluation. J Ayurveda Integr Med 10: 102-110, 2019.

34. Elledge SJ: Cell cycle checkpoints: Preventing an identity crisis. Science 274: 1664-1672, 1996.

35. Campbell JB, Reece JB, Urry LA, Cain ML, Wasserman SA Minorsky PV and Jackson RB: Biology. 8th edition. Pearson Eucation, Inc., San Francisco, CA, 2008.

36. Xu W, Zhu Q, Zhang B, Liu S, Dai X, Gao C, Gao L and Cui Y: Protective effect of calretinin on testicular leydig cells via the inhibition of apoptosis. Aging (Albany NY) 9: 1269-1279, 2017.
37. Liu L, Wang D, Li L, Ding X and Ma H: Dehydroepiandrosterone inhibits cell proliferation and improves viability by regulating $\mathrm{S}$ phase and mitochondrial permeability in primary rat leydig cells. Mol Med Rep 14: 705-714, 2016.

38. Tong KL, Chan KL, AbuBakar S, Low BS, Ma HQ and Wong PF: The in vitro and in vivo anti-cancer activities of a standardized quassinoids composition from Eurycoma longifolia on LNCaP human prostate cancer cells. PLoS One 10: e0121752, 2015.

39. Al-Salahi OSA, Ji D, Majid AMSA, Kit-Lam C, Abdullah WZ, Zaki A, Din SKKJ, Yusoff NM and Majid ASA: Anti-tumor activity of Eurycoma longifolia root extracts against K-562 cell line: In vitro and in vivo study. PLoS One 9: e83818, 2014.

40. Gomi H, Sassa T, Thompson RF and Itohara S: Involvement of cyclin-dependent kinase-like 2 in cognitive function required for contextual and spatial learning in mice. Front Behav Neurosci 4: 17, 2010.

41. Fang CL, Uen YH, Chen HK, Hseu YC, Lin CC, Hung ST, Sun DP and Lin KY: Loss of cyclin-dependent kinase-like 2 predicts poor prognosis in gastric cancer, and its overexpression suppresses cells growth and invasion. Cancer Med 7: 2993-3002, 2018.

42. Zhang J, Su G, Lin Y, Meng W, Lai JKL, Qiao L, Li X and Xie X: Targeting cyclin-dependent kinases in gastrointestinal cancer therapy. Discov Med 27: 27-36, 2019.

43. Li L, Liu C, Amato RJ, Chang JT, Du G and Li W: CDKL2 promotes epithelial-mesenchymal transition and breast cancer progression. Oncotarget 5: 10840-10853, 2014.

This work is licensed under a Creative Commons Attribution-NonCommercial-NoDerivatives 4.0 International (CC BY-NC-ND 4.0) License. 